\title{
PERKEMBANGAN MONETER, PERBANKAN \\ DAN SISTEM PEMBAYARAN \\ TRIWULAN II - 2004
}

Tim Penulis Laporan Triwulanan II - 2004, Bank Indonesia

Selama triwulan II-2004 perkembangan indikator-indikator ekonomi makro masih sejalan dengan prakiraan di awal tahun. Hal ini antara lain ditunjukkan dari pertumbuhan PDB yang sesuai dengan prakiraan, pertumbuhan ekspor yang lebih baik dibandingkan triwulan sebelumnya, serta perkembangan besaran moneter dan fiskal yang relatif terkendali. Namun demikian, peningkatan inflasi dan gejolak nilai tukar rupiah yang terjadi dalam periode laporan perlu diwaspadai dengan seksama. Dalam kondisi yang demikian, upaya mempertahankan stabilitas ekonomi makro menjadi penting untuk dilakukan dan diperkuat. Terkait dengan hal tersebut, Bank Indonesia telah menerapkan Paket Kebijakan Stabilisasi nilai tukar dan kebijakan moneter yang cenderung ketat. Paket kebijakan tersebut dipandang telah cukup efektif untuk menyerap kelebihan likuiditas di sistem perbankan sehingga dapat mengurangi potensi penggunaan dana yang dapat mengganggu kestabilan nilai tukar rupiah lebih lanjut.

Pertumbuhan ekonomi triwulan II-2004 diperkirakan tetap membaik sesuai prakiraan semula yaitu sekitar 4,2-4,7\% (y-o-y). Pertumbuhan tersebut masih bertumpu pada konsumsi, sementara pertumbuhan investasi dan ekspor diperkirakan tumbuh dengan tingkat yang terbatas. Secara sektoral, pertumbuhan positif terjadi di seluruh sektor kecuali sektor pertambangan, dengan pertumbuhan tertinggi pada sektor sektor pengangkutan, perdagangan, dan listrik.

Inflasi IHK sampai dengan akhir triwulan II-2004 mencapai 6,83\% (yoy), lebih tinggi dari prakiraan awal triwulan sebesar 5-6\% (y-o-y). Secara umum, inflasi IHK pada triwulan II-2004 terutama disebabkan oleh melemahnya nilai tukar yang meningkatkan ekspektasi inflasi masyarakat. Sementara itu, tekanan inflasi dari sisi permintaan masih rendah kecuali untuk sejumlah komoditas bahan makanan yang terkait dengan faktor musiman.

Nilai tukar rupiah mengalami tekanan yang cukup berat disertai dengan peningkatan volatilitas. Dalam triwulan II-2004, rupiah melemah 6,3\% hingga secara rata-rata kurs rupiah mencapai Rp9.005 per dolar AS. Pelemahan rupiah tersebut dimulai pada awal Mei 2004 
sebagai dampak rambatan penguatan dolar AS secara global dan kenaikan harga minyak dunia. Perkembangan tersebut telah mendorong sentimen untuk melepas portofolio dalam bentuk rupiah (capital outflows) terutama yang berjangka waktu pendek oleh pelaku asing. Tekanan depresiasi rupiah semakin meningkat karena dari sisi domestik terjadi peningkatan permintaan valas oleh korporasi dan BUMN (bandwagon effect). Namun, sejalan dengan membaiknya ekspektasi pasar yang positif serta cukup efektifnya implementasi Paket Kebijakan Stabilisasi nilai tukar yang ditempuh oleh Bank Indonesia, dalam awal bulan Juli 2004 nilai tukar rupiah mulai bergerak stabil bahkan telah menunjukkan kecenderungan menguat hingga mencapai Rp8.990 per dolar AS.

Sejumlah indikator utama moneter juga menunjukkan perkembangan yang relatif stabil dalam triwulan II-2004 dan sebagian besar masih sesuai dengan prakiraan semula. Suku bunga SBI 1 bulan dan 3 bulan relatif stabil pada level 7,34\% dan 7,25\%, sementara suku bunga FASBI pagi dan sore juga mengalami penurunan $7 \%$ dan $3,5 \%$. Penurunan suku bunga juga terjadi pada semua jenis kredit dengan penurunan terbesar pada kredit konsumsi, sementara suku bunga deposito menunjukkan peningkatan. Seiring dengan tekanan depresiasi nilai tukar rupiah yang terjadi dan meningkatnya ekspektasi inflasi, Bank Indonesia mempertahankan suku bunga instrumen moneter pada level yang stabil. Di sisi besaran moneter, perkembangan uang primer masih terkendali dan sejalan dengan pertumbuhan rata-rata tahunannya.

Kinerja perbankan dalam triwulan II-2004 secara keseluruhan tetap stabil dan tidak terdapat potensi peningkatan risiko yang dapat membahayakan stabilitas sistem keuangan. Berdasarkan data Mei 2004, secara umum indikator-indikator utama perbankan memperlihatkan perbaikan. Kualitas kredit secara industri tidak menunjukkan perubahan sebagaimana yang ditunjukkan oleh NPL gross dan netto. Di sisi lain, rentabilitas dan permodalan perbankan menunjukkan tingkat yang memadai. Penyaluran kredit perbankan juga meningkat sehingga telah meningkatkan LDR perbankan.

Dalam triwulan mendatang, Bank Indonesia memandang bahwa prospek makroekonomi pada triwulan III-2004 dan keseluruhan tahun 2004 masih sesuai dengan prakiraan awal tahun. Pertumbuhan ekonomi pada triwulan III-2004 diperkirakan akan berada pada kisaran 4,6 - 5,1\% (y-o-y). Meskipun kondisi ekonomi makro diperkirakan akan terus membaik, Bank Indonesia menilai perlu dilakukan langkah-langkah untuk melepaskan ketergantungan pertumbuhan ekonomi terhadap kegiatan konsumsi. Selain itu, langkahlangkah yang efektif untuk meningkatkan investasi dan ekspor perlu ditingkatkan. Di sektor eksternal, ekspor non migas diperkirakan akan tumbuh sekitar 6,5\%. Seiring dengan itu, 
transaksi berjalan diperkirakan akan membaik. Kondisi fundamental ekonomi yang diperkirakan akan terus membaik tersebut diharapkan akan memberikan dampak positif terhadap perkembangan nilai tukar rupiah ke depan. Sejalan dengan itu, inflasi IHK pada triwulan III-2004 dan keseluruhan 2004 diperkirakan akan mendekati batas atas prakiraan semula.

Mencermati perkembangan ekonomi-moneter di atas, dalam triwulan mendatang Bank Indonesia akan tetap mempertahankan kebijakan moneter yang berhati-hati dalam rangka mencapai sasaran inflasi jangka menengah panjang. Kebijakan tersebut ditujukan untuk menyerap likuiditas rupiah secara optimal dengan mengupayakan dampak minimal terhadap kenaikan suku bunga. Di bidang perbankan, Bank Indonesia akan melanjutkan langkahlangkah pengawasan khususnya dalam mengantisipasi peningkatan risiko dan penurunan kinerja perbankan antara lain melalui pemantauan terhadap beberapa aspek yang terkait dengan pemberian kredit baru dan kredit yang direstrukturisasi, rencana implementasi manajemen risiko dan pelaksanaan rencana bisnis bank yang telah disetujui pada akhir April 2004.

Secara keseluruhan, laporan triwulan II-2004 ini mencakup evaluasi pelaksanaan tugas dan wewenang Bank Indonesia di bidang moneter, perbankan, dan sistem pembayaran dengan penekanan pada evaluasi pencapaian sasaran inflasi dan sasaran moneter lainnya. Sistematika penyajian laporan terbagi dalam beberapa bab. Bab 2 memaparkan evaluasi Bank Indonesia atas perkembangan kinerja makroekonomi dan kinerja inflasi. Selanjutnya bab 3, 4, 5 masing-masing memaparkan evaluasi atas kebijakan dan perkembangan di bidang moneter, perbankan, dan sistem pembayaran. Bab 6 mengemukakan pandangan Bank Indonesia mengenai prospek ekonomi dan arah kebijakan mendatang termasuk permasalahan yang dihadapi perekonomian dan berbagai langkah yang akan ditempuh Bank Indonesia untuk mengatasinya. Dalam lampiran laporan ini juga disampaikan evaluasi kebijakan di bidang manajemen intern serta produk-produk hukum Bank Indonesia selama triwulan laporan.

\section{Evaluasi Perkembangan Ekonomi Makro dan Inflasi}

\subsection{Kinerja Ekonomi Makro}

Dalam triwulan II-2004 perkembangan ekonomi global menunjukkan peningkatan sebagaimana ditunjukkan oleh naiknya permintaan agregat dan turunnya angka pengangguran negara-negara utama. Di pasar komoditas, harga beberapa komoditas penting 
non migas terutama komoditas industri dan pertambangan masih tinggi walaupun pada akhir periode mulai menunjukkan penurunan. Peningkatan ekonomi global dan pasar komoditas internasional tersebut belum dimanfaatkan secara optimal untuk mendukung kinerja Neraca Pembayaran Indonesia. Hal tersebut ditunjukkan dari terbatasnya akselerasi peningkatan ekspor non migas. Neraca transaksi berjalan dalam triwulan II-2004 tetap mengalami surplus sebesar USD 1,3 miliar, meskipun lebih rendah dibandingkan dengan surplus yang terjadi pada triwulan yang sama tahun sebelumnya.

Secara keseluruhan kegiatan ekonomi pada triwulan II-2004 diperkirakan tumbuh moderat sesuai perkiraan semula yaitu sekitar 4,2-4,7\% (y-o-y). Kegiatan konsumsi masih menjadi penggerak utama perekonomian dan diprakirakan tumbuh sebesar 5,9-6,4\%. Peningkatan konsumsi tersebut antara lain tercermin dari peningkatan penjualan berbagai jenis barang termasuk barang tahan lama seperti mobil dan kebutuhan rumah tangga lainnya, peningkatan pendapatan dan peningkatan pembiayaan konsumen. Sementara itu, investasi dan ekspor diperkirakan tumbuh terbatas. Pengeluaran investasi tumbuh sebesar 1,9 $2,4 \%$, relatif sama dibandingkan dengan triwulan yang sama tahun sebelumnya, terutama disebabkan oleh kecenderungan sikap investor yang masih menunggu situasi politik yang kondusif, sebagaimana tercermin dari penurunan persetujuan investasi PMA dan masih terbatasnya pembiayaan investasi.

Kinerja ekspor pada triwulan II-2004 mengalami pertumbuhan sebesar 2,3-2,8\%, lebih tinggi dibandingkan dengan triwulan sebelumnya sebesar $0,85 \%$. Sumber peningkatan ekspor ini terutama berasal dari 10 komoditi unggulan yang memberikan kontribusi $52 \%$ dari total ekspor. Sementara itu, impor mengalami peningkatan sebesar 6,5\%-7,0\% sedikit lebih tinggi dibandingkan dengan pertumbuhan triwulan yang sama tahun sebelumnya. Peningkatan terjadi pada keseluruhan kelompok barang khususnya barang baku impor termasuk migas.

Secara sektoral, seluruh sektor ekonomi diperkirakan mengalami pertumbuhan positif dengan sektor pengangkutan dan komunikasi, sektor perdagangan dan sektor listrik, gas dan air bersih mencatat pertumbuhan tertinggi. Pertumbuhan di sektor pengangkutan yang tinggi sebesar $11,8 \%$ terutama didukung oleh kinerja subsektor komunikasi dan angkatan udara, seiring dengan perluasan jaringan telekomunikasi oleh beberapa operator telepon dan dengan penambahan rute dan armada penerbangan oleh berbagai maskapai penerbangan. Sektor perdangangan diperkirakan tumbuh 6,9\%, sementara sektor listrik, gas dan air bersih diperkirakan tumbuh $5,6 \%$. 


\section{Tabel 1.1. Indikator Makroekonomi}

\begin{tabular}{|c|c|c|c|c|c|}
\hline \multirow{2}{*}{ Indikator } & \multicolumn{2}{|c|}{2003} & \multicolumn{3}{|c|}{2004} \\
\hline & Trw II & Trw III & Trw IV & Trw I & Trw II \\
\hline \multicolumn{6}{|l|}{$\operatorname{IHK}(\%)$} \\
\hline Triwulanan (quarter to quarter) & 0,46 & 1,24 & 2,51 & 0,91 & 2,35 \\
\hline Tahunan (year on year) & 6,62 & 6,20 & 5,06 & 5,11 & 6,83 \\
\hline PDB (\% pertumbuhan, tahunan) & 3,65 & 3,97 & 4,35 & 4,30 & $4,20-4,70^{*}$ \\
\hline \multicolumn{6}{|l|}{ Dari sisi permintaan: } \\
\hline Konsumsi Total & 4,64 & 4,75 & 5,01 & 4,60 & $5,9-6,4^{*}$ \\
\hline Investasi Total & $-5,39$ & $-1,15$ & $-6,71$ & 1,00 & $1,9-2,4^{*}$ \\
\hline \multicolumn{6}{|l|}{ Dari sisi produksi : } \\
\hline Pertanian & 1,18 & 3,06 & $-0,17$ & 2,17 & $3,4^{*}$ \\
\hline Pertambangan & 0,96 & $-1,27$ & 3,19 & 1,77 & $-0,9^{*}$ \\
\hline Industri Pengolahan & 3,45 & 3,57 & 3,87 & 3,48 & $4,4^{*}$ \\
\hline \multicolumn{6}{|l|}{ Sektor eksternal : } \\
\hline Ekspor non migas (fob, $\%$ pertumbuhan tahunan) & 0,88 & $-4,82$ & 2,36 & $0,50^{*}$ & 3,8 \\
\hline Impor non migas (c\&f, $\%$ pertumbuhan tahunan) & 2,91 & $-10,69$ & 8,55 & $0,85^{*}$ & 7,5 \\
\hline Transaksi berjalan (juta USD) & 2.325 & 2.363 & 1.467 & $1.413^{*}$ & 1.324 \\
\hline Posisi Utang LN (juta USD) & 130.585 & 131.952 & 134.851 & $134.398^{* *}$ & $134.530 * *$ \\
\hline \multicolumn{6}{|l|}{ Besaran Moneter (miliar RP) } \\
\hline M0 & 132.403 & 136.471 & 166.474 & 142.730 & $155.466^{* * *}$ \\
\hline M1 & 181.239 & 195.219 & 207.587 & 223.799 & $223.891^{* * *}$ \\
\hline M2 & 877.776 & 894.554 & 911.223 & 955.692 & $952.962^{* * *}$ \\
\hline \multicolumn{6}{|l|}{ Suku bunga $(\%)^{1)}$} \\
\hline SBI 1 bulan & 11,40 & 9,53 & 8,66 & 8,31 & 7,34 \\
\hline PUAB (overnight) & 12,70 & 8,95 & 4,89 & 4,65 & 4,39 \\
\hline Deposito 1 bulan & 11,90 & 10,31 & 7,67 & 6,62 & $6,16^{* *}$ \\
\hline Kredit modal kerja & 18,08 & 17,41 & 16,07 & 15,07 & $14,27^{* * *}$ \\
\hline Kredit investasi & 17,85 & 17,43 & 16,53 & 15,68 & $14,78^{* * *}$ \\
\hline KURS (RP/USD), NOMINAL AKHIR PERIODE & $\underline{8.693}$ & $\underline{8.275}$ & $\underline{8.395}$ & $\underline{8.420}$ & 9.401 \\
\hline Real Effective Exchange Rate (REER)2), 1995=100 & 87,2 & 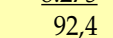 & 88,5 & $\frac{189,2}{89,2}$ & 83,03 \\
\hline Kurs rata-rata & 8.902 & 8.488 & 8.431 & 8.474 & 9.392 \\
\hline \multicolumn{6}{|c|}{$\begin{array}{l}\text { 1) Rata-rata tertimbang akhir periode } \\
\text { 2) REER adalah indeks nilai tukar rupiah per mata uang negara mitra dagang yang dibobot dengan total ekspor dan impor dari } 8 \text { mitra dagang } \\
\text { utama Indonesia. }\end{array}$} \\
\hline
\end{tabular}

\subsection{Kinerja Inflasi}

Laju inflasi selama triwulan II-2004 menunjukkan kenaikan. Inflasi IHK triwulan II-2004 mencapai 2,35\% (q-t-q) dan secara tahunan inflasi IHK meningkat menjadi 6,83\% (y-o-y). Dengan perkembangan tersebut, realisasi inflasi IHK triwulan II-2004 melebihi perkiraan atau proyeksi pada triwulan sebelumnya sebesar 5-6\% (y-o-y).

Selama triwulan laporan, inflasi IHK terutama disebabkan oleh melemahnya nilai tukar, kenaikan tarif telepon, dan penurunan pasokan sejumlah komoditas yang tergolong volatile 
food terkait dengan faktor musiman. Berbagai hal tersebut telah mendorong terbentuknya ekspektasi masyarakat yang memburuk terhadap inflasi. Sementara itu, tekanan inflasi dari sisi permintaan masih rendah karena relatif terjaganya pasokan. Selain itu, meningkatnya inflasi dunia juga mempengaruhi kenaikan harga dalam negeri (imported inflation) yang diindikasikan oleh meningkatnya IHPB impor.

\section{Evaluasi Perkembangan dan Kebijakan Moneter}

Secara umum, pelaksanaan kebijakan moneter sepanjang triwulan II-2004 diarahkan untuk mendukung kestabilan moneter dan kondusif bagi kelangsungan pertumbuhan ekonomi. Sejumlah indikator utama moneter menunjukkan perkembangan yang relatif stabil dalam triwulan II-2004 dan sebagian besar masih sesuai dengan prakiraan semula. Suku bunga SBI 1 bulan dan 3 bulan relatif stabil, yang diikuti oleh stabilnya suku bunga dan volume transaksi di pasar uang antar bank (PUAB). Perkembangan base money terkendali dan masih sejalan dengan pertumbuhan rata-rata tahunannya.

Sementara itu, untuk mengatasi gejolak nilai tukar yang dikhawatirkan dapat menciptakan gangguan pada kestabilan makroekonomi dan pencapaian sasaran inflasi, Bank Indonesia telah menempuh paket kebijakan yang komprehensif. Kebijakan tersebut terutama difokuskan untuk mengendalikan sisi likuiditas rupiah di sistem perbankan yang belum dapat dimanfaatkan oleh sektor riil dan menyempurnakan ketentuan kehati-hatian perbankan dalam melakukan transaksi valas.

Selama triwulan II-2004, nilai tukar rupiah mengalami tekanan yang cukup tajam dan disertai dengan peningkatan volatilitas dibandingkan triwulan sebelumnya. Secara ratarata, rupiah melemah 6,3\% hingga mencapai Rp9.005 pada triwulan II-2004. Pelemahan rupiah tersebut merupakan dampak rambatan penguatan dolar AS secara global, terkait dengan ekspektasi kenaikan suku bunga Fed dan percepatan pemulihan ekonomi AS. Perkembangan tersebut telah mendorong sentimen untuk melepas portofolio dalam bentuk rupiah (capital outflows) oleh pelaku asing. Tekanan depresiasi rupiah semakin menguat karena dari sisi domestik terjadi peningkatan permintaan valas oleh korporasi dan BUMN (bandwagon effect). Tekanan dari sisi domestik ini terus berlanjut meskipun dolar AS telah kembali terkoreksi pada akhir Mei ketika Fed memberikan sinyal bahwa kenaikan suku bunga akan dilakukan secara gradual dan perbaikan indikator makro AS ternyata tidak secepat yang diperkirakan.

Menghadapi tingginya permintaan valas, Bank Indonesia secara terukur melakukan langkah sterilisasi valas untuk mendukung sisi pasokan dan menjaga kepercayaan pasar. 
Selain itu, Bank Indonesia juga melakukan monitoring transaksi valas perbankan yang diperkuat dengan diimplementasikannya Paket Kebijakan Stabilisasi Ekonomi yang mencakup tiga aspek. Pertama, kebijakan pengendalian di sisi likuiditas rupiah dengan menyerap kelebihan likuiditas perbankan yang belum dapat dimanfaatkan oleh sektor riil melalui pengaktifan FASBI berjangka 7 hari dan peningkatan GWM bank; kedua, penyempurnaan ketentuan kehati-hatian perbankan berkaitan dengan ketentuan PDN; ketiga, peningkatan pemantauan permintaan valas. Dengan perkembangan tersebut, dalam minggu pertama bulan Juli 2004 nilai tukar rupiah mulai stabil bahkan telah menunjukkan kecenderungan menguat hingga mencapai Rp8.990 per dolar AS.

Kecenderungan melemahnya nilai tukar rupiah dan meningkatnya ekspektasi inflasi telah menyebabkan melambatnya akselerasi penurunan suku bunga SBI sehingga dalam dua bulan terakhir suku bunga SBI relatif stabil. Dalam triwulan II-2004, suku bunga SBI 1 bulan dan 3 bulan relatif stabil pada level 7,34\% dan 7,25\%. Melambatnya penurunan suku bunga SBI serta rencana kenaikan GWM relatif tidak berdampak pada rata-rata volume dan suku bunga PUAB. Hal ini didorong oleh masih tingginya ekses likuiditas perbankan, terutama di bank-bank besar. Sementara itu, perkembangan suku bunga dana dan kredit diwarnai dengan kecenderungan peningkatan suku bunga deposito dan berlanjutnya trend penurunan suku bunga kredit. Suku bunga deposito 1 bulan dan 3 bulan naik 36 bps menjadi $6,16 \%$ dan 6 bps menjadi $6,17 \%$, sementara suku bunga kredit menurun menjadi 14,27\% (Kredit Modal Kerja), 14,78\% (Kredit Investasi) dan 17,68\% (Kredit Konsumsi).

Seiring dengan meningkatnya kegiatan perekonomian dan inflasi pada triwulan II2004, pertumbuhan uang primer menunjukkan peningkatan. Secara rata-rata pertumbuhan uang primer sementara sepanjang triwulan II-2004 tumbuh 16,00\%, sementara posisi uang primer pada akhir triwulan II-2004 meningkat sebesar Rp13,45 triliun dari triwulan sebelumnya menjadi Rp156,27 triliun.

\section{Evaluasi Perkembangan dan Kebijakan Perbankan}

Selama triwulan II-2004, kebijakan di bidang perbankan tetap difokuskan pada berbagai langkah untuk memperkokoh sistem keuangan terutama melalui pemantapan ketahanan sistem perbankan. Langkah tersebut dilakukan melalui: pemantauan persiapan pelaksanaan manajemen risiko, pemantauan intensif terhadap pelaksanaan rencana bisnis bank yang telah disetujui Bank Indonesia, pemantauan pemberian kredit baru dan kredit hasil restrukturisasi terutama di bank-bank besar, pemantauan action plan dari bank-bank dengan 
CAR dibawah $8 \%$ dan berada di sekitar batas minimal serta bank-bank dengan NPL lebih dari $5 \%$, serta melalui penyempurnaan pengaturan dan pengawasan bank.

Pada triwulan II-2004 Bank Indonesia telah mengeluarkan tiga ketentuan berkaitan dengan perbankan konvensional yakni : (i) Ketentuan yang mengatur kembali sistem penilaian tingkat kesehatan bank umum khusus untuk bank yang melakukan kegiatan usaha secara konvensional, (ii) Ketentuan yang mengatur Giro Wajib Minimun (GWM) dalam rupiah dan valas sebagai salah satu upaya untuk mempertahankan stabilitas moneter, (iii) Ketentuan yang mengatur bahwa bank yang menyelenggarakan internet banking wajib menerapkan manajemen risiko pada aktivitas internet banking secara efektif.

Sejalan dengan itu, kinerja perbankan dalam triwulan II-2004 secara keseluruhan menunjukkan kestabilan dan tidak terdapat potensi peningkatan risiko yang dapat membahayakan stabilitas sistem keuangan, meskipun dalam bulan April 2004 terdapat penutupan dua bank yakni Bank Dagang Bali dan Bank Asiatic. Berdasarkan data Mei 2004, secara umum indikator-indikator utama perbankan memperlihatkan perbaikan. Kualitas kredit secara industri tidak menunjukkan perubahan sebagaimana yang ditunjukkan oleh NPL gross dan net. Di sisi lain, rentabilitas dan permodalan perbankan menunjukkan tingkat yang memadai. Sementara itu, penyaluran kredit perbankan menunjukkan peningkatan sehingga telah meningkatkan LDR perbankan

Sampai dengan triwulan II-2004, total aset perbankan meningkat 2,6\% menjadi Rp1.179 triliun yang didukung oleh peningkatan kredit sebesar Rp27,5 triliun (5,7\%) sehingga menjadi Rp 513,4 triliun. Dengan demikian, pangsa kredit terhadap aktiva produktif mencapai 47,0\%; meningkat dibanding periode sebelumnya sebesar 45,0\%. Sementara itu, kredit baru yang disetujui dan ditarik pada periode laporan mencapai $\mathrm{Rp} 13,7$ triliun, meningkat $113,3 \%$ dibanding triwulan sebelumnya, dengan total kredit baru tahun 2004 yang telah ditarik sampai dengan Mei 2004 mencapai Rp 20,2 triliun. Sebagian besar kredit baru tersebut merupakan kredit UMKM (52,3\%) dengan komposisi penggunaan untuk KMK sebesar 47,8\%, $\mathrm{KI}$ sebesar $28,1 \%$ serta KK sebesar $24,1 \%$.

Meskipun nilai rupiah melemah terhadap valas, kepercayaan nasabah penyimpan terhadap perbankan masih cukup tinggi yang tampak dari kenaikan DPK menjadi Rp895,1 triliun. Kenaikan tersebut memungkinkan perbankan melakukan ekspansi termasuk dalam bentuk kredit, sehingga loan to deposit ratio (LDR) pada akhir periode laporan membaik menjadi $45,6 \%$ dari akhir periode sebelumnya sebesar $43,7 \%$.

Disisi kredit bermasalah, NPL gross perbankan selama periode laporan tetap stabil sekitar 7,8\%, sementara NPL netto tetap dibawah batas $5 \%$, bahkan sedikit membaik menjadi 
$2,4 \%$ dari akhir tahun sebelumnya yang tercatat sebesar $3 \%$. Dengan total aktiva produktif mencapai Rp1.093,4 triliun, rentabilitas perbankan masih memadai meskipun sedikit menurun sebagaimana ditunjukkan dengan penurunan ROA yang menjadi $2,6 \%$ dari $2,7 \%$. Selain itu, Net Interest Margin (NIM) industri perbankan relatif tetap sejak awal tahun 2004 yaitu sebesar $0,5 \%$ dan dari sisi efisiensi, rasio Beban Operasional Pendapatan Operasional (BOPO) pada akhir periode laporan mencapai $87,7 \%$ atau lebih baik dibandingkan periode sebelumnya. Demikian pula permodalan industri perbankan pada triwulan II-2004 tetap memadai yaitu sebesar $21,4 \%$.

Sejalan dengan relatif membaiknya kinerja bank umum, kinerja BPR dan bank syariah juga menunjukkan perkembangan yang sama. Berdasarkan data triwulan I-2004, DPK yang dihimpun BPR meningkat 4,4\% sehingga menjadi Rp9.254 miliar, sementara kredit meningkat 5\% menjadi Rp9.431 miliar. Di sisi Bank Syariah, berdasarkan data Mei 2004, aset perbankan syariah meningkat cukup tinggi sehingga mencapai Rp11,6 triliun, dengan didukung oleh pertumbuhan jaringan yang mencapai 365 kantor. Perluasan jaringan kantor perbankan yang mencapai $40 \%$ (y-o-y) tersebut diikuti pula oleh kenaikan permodalan perbankan syariah yang saat ini secara industri berada di sekitar $15 \%$. Dari sisi pendanaan, DPK meningkat cukup besar menjadi sebesar Rp7,8 triliun. Sementara itu, jumlah pembiayaan yang diberikan mencapai Rp7,6 triliun.

\section{Evaluasi Perkembangan dan Kebijakan Sistem Pembayaran}

Secara umum, kebijakan yang ditempuh dalam sistem pembayaran tunai tetap diarahkan pada upaya pemenuhan kebutuhan uang rupiah di masyarakat dalam jumlah nominal yang cukup, jenis pecahan yang sesuai, tepat waktu dan dalam kondisi yang layak edar. Sementara kebijakan yang ditempuh dalam sistem pembayaran non tunai, diarahkan pada terciptanya sistem pembayaran yang efektif, efisien, aman, dan handal.

Di sisi pembayaran tunai, aktivitas pembayaran tunai dalam triwulan II-2004 mengalami peningkatan yang ditunjukkan dari meningkatkanya jumlah uang yang diedarkan serta net outflow pengedaran uang yang dilakukan Kantor Bank Indonesia (KBI). Meningkatkanya aktivitas pembayaran uang tunai tersebut terutama terkait dengan meningkatnya kebutuhan masyarakat terhadap uang tunai sehubungan dengan Pemilu dan liburan sekolah. Posisi Uang Yang Diedarkan (UYD) pada akhir triwulan II-2004 meningkat 11,05\%, dari Rp102,27 triliun pada triwulan I-2004 menjadi Rp113,56 triliun pada triwulan II-2004.

Di sisi pembayaran non-tunai, total transaksi BI-RTGS pada triwulan II-2004 mencapai Rp6.103 triliun atau menurun 9,3\% dibandingkan triwulan sebelumnya sebesar Rp6.729 
triliun. Sementara itu, volume transaksi mencapai 1.217 ribu, atau naik sebesar $8,4 \%$ dari 1.123 ribu transaksi pada triwulan sebelumnya. Kondisi tersebut menyebabkan rata-rata harian nominal transaksi mencapai Rp101,7 triliun sementara rata-rata harian volume transaksi mencapai 20.298 transaksi. Ditinjau dari wilayah asal perintah transaksi RTGS, maka secara nominal transaksi transfer dana yang melalui RTGS didominasi oleh wilayah Jakarta.

Sementara itu, perkembangan aktivitas kliring selama triwulan II-2004 mengalami peningkatan baik dari sisi nominal maupun jumlah lembar warkat yang diproses. Total nominal kliring penyerahan secara nasional mencapai Rp319 triliun dengan warkat sejumlah 19,9 juta lembar. Hal ini menunjukkan masing-masing peningkatan nilai transaksi sebesar $8,5 \%$ dan volume transaksi sebesar 9,9\% dibandingkan triwulan sebelumnya. Dengan demikian, rata-rata harian nominal dan volume naik masing-masing sebesar $8,2 \%$ menjadi $\mathrm{Rp5,3}$ triliun dan 9,9\% menjadi 332 ribu warkat.

\section{Prospek Ekonomi dan Moneter serta Arah Kebijakan Ke Depan}

\subsection{Prospek Ekonomi Makro}

Kondisi perekonomian dunia yang terus membaik seiring dengan meningkatnya kegiatan ekonomi dan perdagangan internasional yang didukung oleh membaiknya optimisme diperkirakan masih mendukung kinerja ekspor, walaupun diwarnai oleh penurunan harga komoditas baik migas maupun non migas. Kinerja ekspor dan impor non migas diperkirakan meningkat dengan laju pertumbuhan masing-masing sebesar 3,9\% dan 8,3\% (yoy). Perkembangan ini memberikan dampak yang positif bagi pertumbuhan ekonomi Indonesia pada triwulan III-2004.

Prospek pertumbuhan ekonomi Indonesia pada triwulan II-2004 diperkirakan akan membaik dibandingkan dengan triwulan sebelumnya dan berada pada kisaran 4,6-5,1\% (yoy). Dari sisi permintaan, sumber utama pertumbuhan pada triwulan laporan masih berasal dari konsumsi yang diperkirakan tumbuh dalam kisaran 6,0-6,5\% (y-0-y). Pertumbuhan investasi diperkirakan akan stagnan seiring dengan sikap menunggu dari para pelaku bisnis pada situasi ekonomi dan politik dewasa ini. Sementara itu, ekspor barang dan jasa diperkirakan akan mengalami peningkatan dengan kisaran 5,5-6,0\%. Peningkatan ekspor tersebut disumbang oleh membaiknya pertumbuhan ekspor non migas yang didorong oleh bertambahnya permintaan dari negara-negara mitra dagang utama seperti Amerika Serikat, Jepang dan negara-negara kawasan Eropa. Sejalan dengan meningkatnya pertumbuhan 
permintaan domestik dan ekspor, pertumbuhan impor barang dan jasa diperkirakan akan melambat dengan sumbangan tertinggi berasal dari impor bahan baku.

\subsection{Prospek Inflasi}

Pada triwulan III-2004, inflasi IHK diperkirakan meningkat sejalan dengan melemahnya nilai tukar rupiah, meningkatnya ekspektasi inflasi dan adanya kebijakan pembatasan impor untuk beberapa komoditas bahan makanan, seperti beras dan gula, serta masih tingginya harga minyak untuk bahan baku industri. Sementara itu, tekanan inflasi yang bersumber dari administered price diperkirakan minimal. Dengan kondisi tersebut, inflasi IHK triwulan III-2004 diperkirakan akan sedikit meningkat dan secara keseluruhan tahun 2004, inflasi IHK diperkirakan akan berada pada batas atas kisaran perkiraan awal tahun $(5,5 \%$ dengan deviasi $\pm 1 \%)$.

\subsection{Prospek Nilai Tukar}

Dalam triwulan III-2004 pasar valas diperkirakan akan mengalami tekanan permintaan seiring dengan meningkatnya impor secara signifikan terkait dengan perkiraan kebutuhan domestik yang masih cukup tinggi baik di sektor migas maupun non migas. Sementara itu, beberapa sentimen dalam dan luar negeri diperkirakan akan berpengaruh terhadap pergerakan rupiah. Dari dalam negeri, masuknya siklus waktu pemilihan Presiden diperkirakan dapat mewarnai pergerakan rupiah. Sementara dari faktor eksternal, perkiraan masuknya perekonomian AS dalam siklus tightening, dalam jangka pendek akan berdampak pada pelemahan hampir semua mata uang dunia terhadap dolar AS. Untuk rata-rata keseluruhan tahun 2004, kurs rupiah diproyeksikan masih berada pada kisaran prakiraan awal tahun.

\subsection{Arah Kebijakan Triwulan Mendatang}

Memperhatikan beberapa tantangan ekonomi dan prospek ekonomi-moneter ke depan, dalam triwulan mendatang arah kebijakan Bank Indonesia di bidang moneter, perbankan, dan sistem pembayaran sebagai berikut :

Di bidang moneter, kebijakan moneter tetap diarahkan pada upaya mempertahankan stabilitas moneter dalam upaya mencapai sasaran inflasi jangka menengah dengan tetap memperkuat proses pemulihan ekonomi dengan mendorong pertumbuhan ekonomi. Terkait 
dengan hal tersebut, kebijakan moneter yang tight bias akan dipertahankan untuk menyerap likuiditas rupiah secara optimal sehingga memberikan dampak yang minimal terhadap kenaikan suku bunga. Di sisi lain, untuk mencegah volatilitas nilai tukar yang berlebihan, intervensi di pasar valas akan dilakukan sesuai kebutuhan sejalan dengan pelaksanaan monitoring dan pengawasan transaksi devisa terhadap pelaku utama di pasar.

Di bidang perbankan, kebijakan diarahkan untuk melanjutkan upaya-upaya untuk mempertahankan stabilitas sistem keuangan dan perbankan serta mendorong peningkatan fungsi intermediasi perbankan. Di samping itu, Bank Indonesia akan meneruskan pelaksanaan Arsitektur Perbankan Indonesia (API), antara lain meliputi pembentukan panel ahli perbankan, mekanisme pengaduan nasabah, pendirian lembaga mediasi perbankan, transparansi informasi produk, edukasi konsumen, Good Corporate Governance, Credit Bureau, sertifikasi manajer risiko, linkage program dan pelonggaran ketentuan pembukaan kantor cabang BPR. Sementara itu, Menteri Keuangan dan Gubernur Bank Indonesia telah menandatangani Nota Kesepakatan Fasilitas Pembiayaan Darurat (FPD) yang merupakan bagian dari kerangka kerja Jaring Pengaman Sektor Keuangan. Dengan adanya Nota Kesepakatan tersebut, maka penanganan dan akuntabilitas dalam penyelesaian bank-bank yang mengalami kesulitan keuangan dan berdampak sistemik menjadi lebih jelas dan transparan.

Di bidang sistem pembayaran tunai, kebijakan tetap diarahkan pada upaya untuk memenuhi uang kartal dalam jumlah yang cukup, pecahan yang sesuai, tepat waktu dan dalam kondisi yang layak edar sesuai dengan kebutuhan masyarakat khususnya menghadapi Pemilu 2004. Di samping itu, Bank Indonesia juga terus meningkatkan koordinasi dengan pihak terkait dalam rangka memperlancar distribusi uang ke seluruh wilayah Indonesia, serta senantiasa melanjutkan upaya-upaya penanggulangan uang palsu antara lain melalui perluasan jejaring dan kerjasama dengan pihak-pihak terkait pada langkah penanggulangan uang palsu. Di sisi lain, dalam upaya mengenalkan masyarakat akan keaslian uang rupiah, dalam triwulan III-2004 Bank Indonesia akan menggunakan media elektronik dan media cetak sebagai sarana publikasi pengenalan ciri-ciri keaslian uang rupiah.

Di bidang sistem pembayaran non tunai, kebijakan tetap diarahkan pada upaya pengurangan risiko pembayaran dan peningkatan efisiensi serta pengaturan pelaksanaan sistem pembayaran guna mewujudkan sistem pembayaran nasional yang efisien, cepat, aman dan handal melalui ujicoba disaster recovery center (DRC), penyusunan mekanisme failure to settle, pengembangan Sistem Kliring Terpadu (SKT), pengembangan Daftar Hitam Nasional dan kajian atas peningkatan peran BPR dalam sistem pembayaran. 